\title{
Determination of Air Quality index (AQI) of Aerosol Particles along Busy Roads in Karachi Metropolitan, Pakistan
}

\author{
Durdana Rais Hashmi* and Akhtar Shareef \\ Centre for Environmental Studies, PCSIR Laboratories Complex, Karachi \\ *Corresponding author: Durdana Rais Hashmi, Centre for Environmental Studies, PCSIR Laboratories Complex, Karachi
}

$\overline{\text { ARTICLE INFO }}$ ABSTRACT

Received: 幽 February 25, 2019

Published: 慧 March 11, 2019

Citation: Durdana Rais Hashmi, Akhtar Shareef. Determination of Air Quality index (AQI) of Aerosol Particles along Busy Roads in Karachi Metropolitan, Pakistan. Biomed J Sci \& Tech Res 15(4)-2019. BJSTR. MS.ID.002745.
This study was carried out to determine the concentration of ambient air quality in terms of air born particulate matter (PM10) at 10 different monitoring locations along the busy roads of Karachi city. Concentrations of particulate matter were used to calculate the results in terms of Air Quality Index (AQI). At each location, the study was carried out continuously for a period of 08 hours in each month during the year 2013 to 2017. Results along the selected sites show that at most of the sites have very poor to hazardous AQI category regarding the PM10 Concentration, exceeds the permissible limits as specified by US-EPA. This high concentration of pollution is very harmful for human health to the residents.

Keywords: Karachi City; Air Quality Index; Ambient Air; Particulate Matter

\section{Introduction}

Air pollution is a global hazard and has immense effects on human health, metrology, climatic changes and ecosystem. In developing countries modernization and industrialization increases the use of fossil fuel in many ways and producing environmental damages especially in rapidly growing megacities [1,2]. According to the World Health Organization (WHO), urban air pollution is responsible for approximately 800,000 deaths annually around the globe [3]. At present Particulate matter pollution is one of the most important issue in urban cities, not only producing adverse health effects, reducing the atmospheric visibility and also affect the status of cultural heritages [4]. [5-7] show a strong association between elevated concentrations of inhalable particulate (PM10) and increased mortality and morbidity. Several researches associated with particulate matter pollution also show increase in hospitalizations, lung function disorder, asthma, bronchitis, other respiratory diseases and premature deaths (Sicard et al., 2011) [8-10].

The air quality index (AQI) is a scale to show or characterize the degree of ambient air pollution at a particular monitoring location during a certain monitoring period (e.g., one, 8 or $24 \mathrm{~h}$ ) due to the concentration of human activities that occur in cities. The main aim of AQI calculation is to aware the public about the risk of pollution level day to day and to prepare for precautionary measurement and to regulate the safety measures for health hazards (Figure 1).

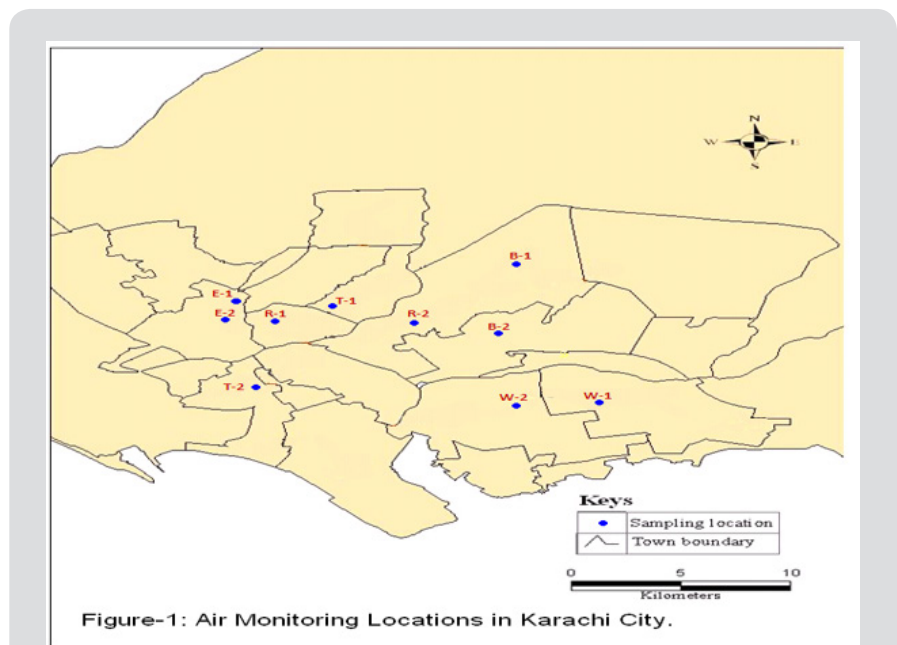

Figure 1: Air monitoring locations in karachi city. 


\section{Materials and Methods}

Sampling was carried out at ten different locations consisting of main roads, side road, round about, and open places along the busy roads of Karachi during 2013 - 2017 for PM10. Selected locations were differentiated as Residential, Commercial and Industrial areas of the Karachi's environment. PM10 samples were collected on glass fiber filters $(203 \times 254 \mathrm{~mm})$ by using high volume air sampler with an average flow rate of $1.0 \mathrm{~m} 3 / \mathrm{min}$. Eight hour sampling was done in duplicate at each location during the year 2013-2017. The high volume is considered a reliable instrument for measuring the weight of PM10 in ambient air (USEPA-Method 40 CFR).

\section{Air Quality Index (AQI)}

In this study AQI has been calculated with reference to the concentration of particulate pollution proposed by US-EPA (USEPA, 2012). Following equation was used to calculate the AQI values by using the pollutant concentration data.

$$
\mathrm{I}_{p}=\frac{\mathrm{IH} i-\mathrm{I} l o}{\mathrm{BPH} i-\mathrm{BP} L o}\left(C_{p} \mathrm{BP} L o\right)+\mathrm{I} L o
$$

After compiling the data, the concentration of PM10 pollutant was converted in to an AQI value for each location, higher the AQI value, higher the level of air pollution and describe the associated health hazards, providing meaning full information to the citizens. The Table 1 shows the air quality index with the category of health risk. The air quality index zero to fifty is good for human health and indicate clean air, 50 to 100 indicate moderate air quality, 101 to 150 point toward unhealthy for sensitive group, 151 to 200 express unhealthy for all people, 200 to 300 very unhealthy, 301 to 500 hazardous and $>500$ indicate sever hazardous (Table 1).

Table 1: AQI criteria and quality category.

\begin{tabular}{|c|c|c|}
\hline AQI & AQI Category & Colour Show the Category \\
\hline $0-50$ & Good & Green \\
\hline $51-100$ & Moderate & Yellow \\
\hline $101-150$ & Unhealthy for Sensitive & Orange \\
\hline $151-200$ & Poor / Unhealthy & Red \\
\hline $201-300$ & Very poor / very unhealthy & Purple \\
\hline $301-500$ & Hazardous & Mahroon \\
\hline
\end{tabular}

Note: Source: US-EPA (2012) and Gurjar et al. [9].

Table 2: AQI values / Category of Aerosol Particles (PM10) at the selected locations in Karachi city.

\begin{tabular}{|c|c|c|c|c|c|c|c|c|c|c|c|c|}
\hline \multirow[t]{2}{*}{ Sr \# } & \multirow[t]{2}{*}{ Locations } & & \multicolumn{2}{|c|}{2013} & \multicolumn{2}{|c|}{2014} & \multicolumn{2}{|c|}{2015} & \multicolumn{2}{|c|}{2016} & \multicolumn{2}{|r|}{2017} \\
\hline & & & AQI Value & $\begin{array}{l}\text { AQI Cate- } \\
\text { gory }\end{array}$ & $\begin{array}{c}\text { AQI } \\
\text { Value }\end{array}$ & $\begin{array}{c}\text { AQI Cat- } \\
\text { egory }\end{array}$ & $\begin{array}{c}\text { AQI } \\
\text { Value }\end{array}$ & $\begin{array}{c}\text { AQI Cat- } \\
\text { egory }\end{array}$ & $\begin{array}{c}\text { AQI } \\
\text { Value }\end{array}$ & $\begin{array}{c}\text { AQI Cat- } \\
\text { egory }\end{array}$ & $\begin{array}{c}\text { AQI } \\
\text { Value }\end{array}$ & AQI Category \\
\hline 1 & Karimabad & C -1 & 122 & unhealthy & 145 & $\begin{array}{c}\text { un- } \\
\text { healthy }\end{array}$ & 180 & Poor & 167 & Poor & 200 & Poor \\
\hline 2 & $\begin{array}{c}\text { Tibet } \\
\text { Centre }\end{array}$ & $C-2$ & 178 & Poor & 210 & Poor & 226 & V.Poor & 200 & Poor & 188 & Poor \\
\hline 3 & $\begin{array}{l}\text { Liaquata- } \\
\text { bad }\end{array}$ & C -3 & 147 & Poor & 186 & Poor & 210 & V.Poor & 173 & Poor & 162 & Poor \\
\hline 4 & PIB Colony & $\mathrm{R}-1$ & 102 & unhealthy & 120 & $\begin{array}{c}\text { un- } \\
\text { healthy }\end{array}$ & 157 & $\begin{array}{c}\text { un- } \\
\text { healthy }\end{array}$ & 130 & $\begin{array}{c}\text { un- } \\
\text { healthy }\end{array}$ & 145 & unhealthy \\
\hline 5 & Nazimabad & $\mathrm{R}-2$ & 108 & Moderate & 123 & $\begin{array}{c}\text { un- } \\
\text { healthy }\end{array}$ & 168 & $\begin{array}{c}\text { un- } \\
\text { healthy }\end{array}$ & 136 & $\begin{array}{c}\text { un- } \\
\text { healthy }\end{array}$ & 155 & unhealthy \\
\hline 6 & $\begin{array}{c}\text { Gulshan-e- } \\
\text { Iqbal }\end{array}$ & $\mathrm{R}-3$ & 67 & Moderate & 100 & $\begin{array}{l}\text { Moder- } \\
\text { ate }\end{array}$ & 142 & $\begin{array}{c}\text { un- } \\
\text { healthy }\end{array}$ & 84 & $\begin{array}{l}\text { Moder- } \\
\text { ate }\end{array}$ & 127 & unhealthy \\
\hline 7 & $\begin{array}{l}\text { Siemens } \\
\text { Chorangi }\end{array}$ & $\mathrm{I}-1 \mathrm{E}$ & 140 & Poor & 167 & Poor & 194 & Poor & 120 & Poor & 183 & Poor \\
\hline 8 & $\begin{array}{l}\text { Naurus } \\
\text { Chorangi }\end{array}$ & $\mathrm{I}-2 \mathrm{E}$ & 127 & unhealthy & 161 & Poor & 179 & Poor & 110 & $\begin{array}{c}\text { un- } \\
\text { healthy }\end{array}$ & 150 & Poor \\
\hline 9 & $\begin{array}{c}\text { Singer } \\
\text { Chorangi }\end{array}$ & $\mathrm{I}-3 \mathrm{~W}$ & 90 & Moderate & 130 & $\begin{array}{c}\text { un- } \\
\text { healthy }\end{array}$ & 164 & $\begin{array}{c}\text { un- } \\
\text { healthy }\end{array}$ & 102 & $\begin{array}{c}\text { un- } \\
\text { healthy }\end{array}$ & 120 & unhealthy \\
\hline 10 & $\begin{array}{l}\text { Chamra } \\
\text { Chorangi }\end{array}$ & $\mathrm{I}-4 \mathrm{~W}$ & 110 & unhealthy & 139 & $\begin{array}{c}\text { un- } \\
\text { healthy }\end{array}$ & 154 & $\begin{array}{c}\text { un- } \\
\text { healthy }\end{array}$ & 106 & $\begin{array}{c}\text { un- } \\
\text { healthy }\end{array}$ & 130 & unhealthy \\
\hline
\end{tabular}

\section{Result and Discussion}

Evaluation of the concentrations of ambient PM10 were determined on the basis of PM10 size fractions at the selected sites in Karachi city. Ambient AQI values has been calculated with the recorded pollutant concentration data of the selected sampling locations, showing the degree / intensity of ambient air pollution category at monitoring locations during a certain monitoring period (e.g., 1, 8 or $24 \mathrm{~h}$ ) due to its surrounding metrology and human activities and its relation to health hazards. Table 2 shows the intensity of the pollution level according to AQI category. Yearly average concentration of PM10 shows rising trend during the year 2013- 2015 and then a little bit start decreasing / controlling for 
specific period. The result suggested that rising trend during the year 2013 to 2017 may be due to civil works for overhead bridges and extension of roads and island at different locations in Karachi, again start rising after 2017 may be due to unplanned development, many fold increase in vehicles on poorly maintained roads and insufficient road spaces, less parking facilities, encroachment on roads and footpath, violation of traffic rules with an alarming traffic management strategy are the main issues of rising trend of urban air pollution. The calculated Air Quality Index values for PM10 shows moderate and unhealthy pollution level in residential areas, poor or unhealthy pollution level found at all the sampling locations in industrial areas, whereas Poor or very unhealthy pollution level has been recorded in commercial areas respectively.

\section{Conclusion}

The present study reveals that the concentration of suspended particulate matter exceeded the permissible standards in highly commercial areas, densely populated residential areas and in industrial areas. High concentration of particulate pollutants has a significant negative impact on the ambient air quality status of Karachi city as in terms of Air Quality Index. The main source of pollutant appears to be vehicular emission as its concentration is highest in the sites located in the busy commercial areas of the city with high traffic density. From the studies it is evident that development and planning of the transport system and social awareness can play a major role in improving the quality of air in the city.

\section{ISSN: 2574-1241}

\section{DOI: $10.26717 /$ BJSTR.2019.15.002745}

Durdana Rais Hashmi. Biomed J Sci \& Tech Res

This work is licensed under Creative Commons Attribution 4.0 License

Submission Link: https://biomedres.us/submit-manuscript.php

\section{References}

1. Colbeck I, Nasir ZA, Ahmad S (2010) The state of ambient air quality in Pakistan -a review. Environmental Science and Pollution Research 17: 49-63.

2. Shah MH, Shaheen N, Nazir R (2012) Assessment of the trace elements level in urban atmospheric particulate matter and source apportionment in Islamabad, Pakistan. Atmospheric Pollution and Research 3: 39-45.

3. Maji S, Ahmed S, Siddiqui WA (2010) Air quality assessment and it relation to potential health impacts in Delhi, India 109(5): 902-909.

4. Van Grieken R, Delalieux F (2004) X-ray spectrometry for air pollution and cultural heritage research. In: "Invited Lectures of the $5^{\text {th }} \mathrm{Gen}$. Conf Balkan Phys. Union, BPU-5 (Eds), Serbian Physical Society, Belgrade, pp. 234-246.

5. DW Dockery, CA Pope III (2006) Health effects of particulate air pollution: Lines that connect. J Air \& Waste Manage Association 56: 709742.

6. HR Anderson, RW Atkinson, JL Peacock, MJ Sweeting, L Marston, et al. (2005) Ambient particulate matter and health effects: publication bias in studies of short-term associations. Epidemiol 16: 155-163.

7. A Analitis, K Katsouyanni, E Dimakopoulou, AKSamoli, Y Nikoloulopoulos, et al. (2006) Short-term effects of ambient particles on cardiovascular and respiratory mortality. Epidemiol 17: 230-233.

8. Sicard P, Lesne O, Alexandre N, Mangin A, Collomp R (2011) Air Quality Trends and Potential Health Effects - Development of an Aggregate Risk Index. Atmos Environ 45: 1145-1153.

9. Gurjar BR, Butler TM, Lawrence MG (2008) Evaluation of Emissions and Air Quality in Megacities. Atmospheric Environment 42: 1593-1606.

10. US EPA (2012) Revised air quality standards for particle pollution and updates to the Air Quality Index (AQI). Office of Air Quality Planning and Standards, EPA 454/R99-010.

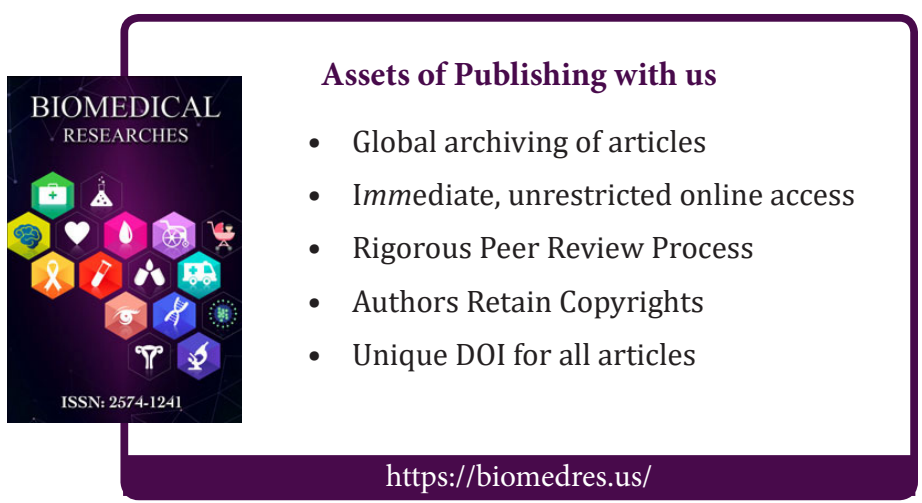

